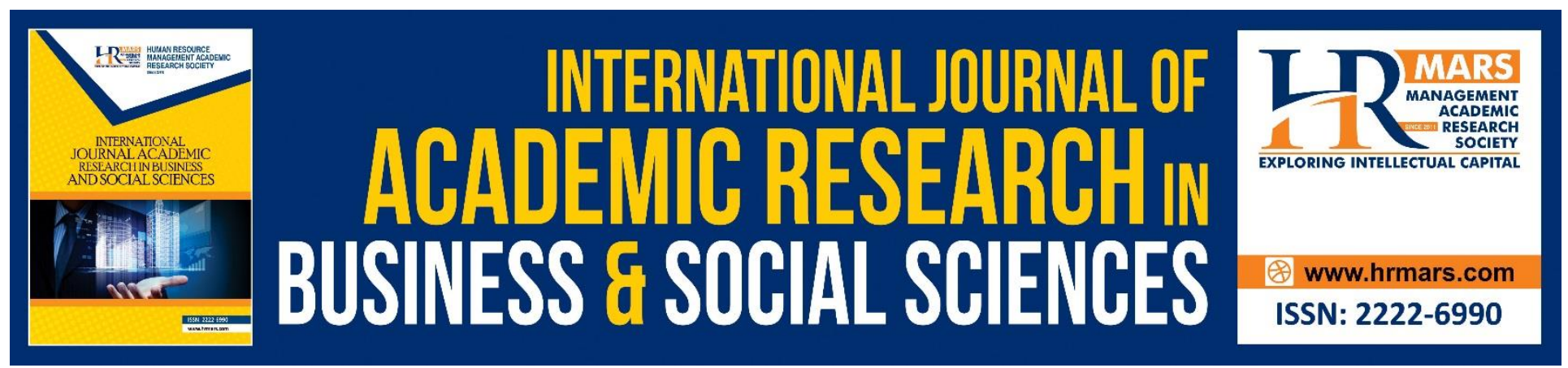

\title{
Probability Model: Malaysian Consumer Online Shopping Behavior towards Online Shopping Scam
}

Mudiana Mokhsin, Azhar Abdul Aziz, Amer Shakir Zainol, Norshima Humaidi \& Nur Ain Adnin Zaini

To Link this Article: http://dx.doi.org/10.6007/IJARBSS/v9-i1/5478

DOI: $\quad 10.6007 /$ IJARBSS/v9-i1/5478

Received: 21 Dec 2018, Revised: 08 Jan 2019, Accepted: 26 Jan 2019

Published Online: 01 Feb 2019

In-Text Citation: (Mokhsin, Aziz, Zainol, Humaidi, \& Zaini, 2019)

To Cite this Article: Mokhsin, M., Aziz, A. A., Zainol, A. S., Humaidi, N., \& Zaini, N. A. A. (2019). Probability Model: Malaysian Consumer Online Shopping Behavior towards Online Shopping Scam. International Journal of Academic Research in Business and Social Sciences, 9(1), 746-755.

\section{Copyright: (C) 2019 The Author(s)}

Published by Human Resource Management Academic Research Society (www.hrmars.com)

This article is published under the Creative Commons Attribution (CC BY 4.0) license. Anyone may reproduce, distribute, translate and create derivative works of this article (for both commercial and non-commercial purposes), subject to full attribution to the original publication and authors. The full terms of this license may be seen at: http://creativecommons.org/licences/by/4.0/legalcode

Vol. 9, No. 1, 2019, Pg. 746 - 755

http://hrmars.com/index.php/pages/detail/IJARBSS

JOURNAL HOMEPAGE

Full Terms \& Conditions of access and use can be found at http://hrmars.com/index.php/pages/detail/publication-ethics 


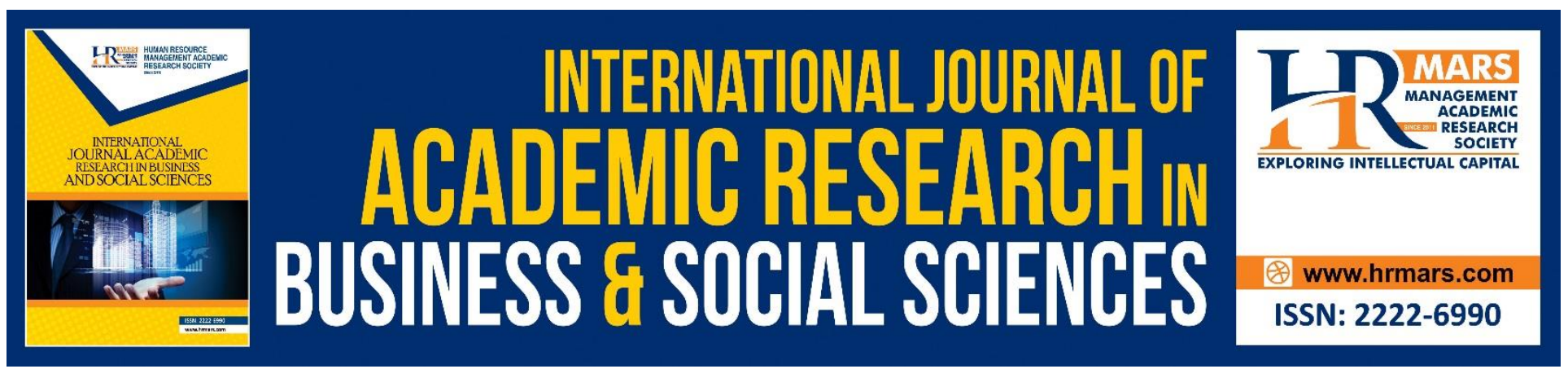

\title{
Probability Model: Malaysian Consumer Online Shopping Behavior towards Online Shopping Scam
}

\author{
${ }^{1}$ Mudiana Mokhsin, ${ }^{2}$ Azhar Abdul Aziz, ${ }^{3}$ Amer Shakir Zainol, \\ ${ }^{4}$ Norshima Humaidi \& ${ }^{5}$ Nur Ain Adnin Zaini \\ 1,2,3,5 Faculty of Computer \& Mathematical Sciences, Universiti Teknologi MARA, 40450 Shah Alam, \\ Selangor, Malaysia \\ ${ }^{1}$ Institute of Malay Thought and Leadership (IMPAK), Universiti Teknologi MARA, 40450 Shah Alam, \\ Selangor, Malaysia \\ ${ }^{4}$ Faculty of Business and Management, Universiti Teknologi MARA, 42300 Puncak Alam, Selangor, \\ Malaysia \\ Email: ${ }^{1}$ mudiana.azhar@tmsk.uitm.edu.my, ${ }^{3}$ amers781@salam.uitm.edu.my, \\ 4norshima954@puncakalam.uitm.edu.my, 5ainzaini11@gmail.com.
}

Abstract

With the rapid development of technology, it has been assisting and connecting people through various platforms such as social networking, data sharing, information storing, online transactions and automated processes. Few years ago, people have been connecting with each other and updating news through social media. Social media has become essentials for their daily lives. Now, apart from functioning as communication platform, people started to use social media as a marketing platform to advertise their business product and services. Social media environment which is functions and navigation that allows online sellers communicate directly with their consumers has successfully made it a great channel for business marketing. However, with the success come its challenges. Consumers are potentially threatened by online shopping scam. Apparently, there are third parties that take advantages on the convenience. They would create a fake account with a fake identity and set up a fake business that looks almost like real to attract consumers to purchase with them. However, once payment has been made, no products or services will be delivered. Some fake sellers would trap consumers to pay some amount of money for a product but in the end, the products received is either different from advertised or lower quality from as per described. The purpose of this study is to explain the definition of online scam and to identify what contribute towards online shopping scam based on consumer online shopping behavior. This study was conducted in Malaysia with total 201 respondents. The data collected were analyzed using Statistical Package for Science Social (SPSS). This study was expected to find the significant factors that contributed towards the probabilities of online shopping scam based on consumer online shopping behavior.

Keywords: Consumer, Behavior, Online Shopping, Online Scam 


\section{Introduction}

Technologies has grown and expand rapidly all over the world connecting and assisting people through social networks, data sharing, storing information, online transactions and automated processes. For the past few decades, people have been adapting technology into their life for example, the use of smartphones. With real-time social media platforms such as Facebook, WeChat and Instagram enable them to connect with other people almost anytime regardless time difference. People get connected easily and a lot of great opportunities come in any area with the help of technology. However, with every innovation come challenges. With numbers of information and data sharing take place virtually, crime activities through internet also increase. Cybercrimes occurred almost every day and it is uncontrollable. It is worrying that some people would take advantages of others for their own benefits. There are various types of cyber-crime such as phishing, blackmailing, fraud, scam, harassment and many more. Cybercrime was seldom targeting individual, property and government. However, individual is more threaten by cyber-crime activities. One might lose all their money without they are noticing it. Cyber Security Malaysia (2014) reported 4,117 cases or 51.6\% of online security incidents involved frauds, including online shopping frauds, and this domination is expected to continue in the future. With at least 46 per cent respondents from this country having admitted to being victim of internet scams, Malaysia leads among the countries surveyed which included India, Singapore and Thailand. These statistic shows that Malaysia network security is not really save and most of Malaysia citizen probably have less knowledge, experience or skill in making sure that they know how to protect their information in social media.

\section{PROBLEM STATEMENT}

With the rapid growth of technology revolution over the years, social media has become essentials to people in term of interacting with their closed, sharing information and updating news. According to Statistica (2015), the social media user numbers has increased tremendously since ever. The year of 2016 has witnessed a high number of social media users that is 68.3 percent which is approximately 2.34 billion. This number is predicted to increase to 2.95 billion in 2020 .

With the social media advancement, its function has been changed from time to time following current trends and environment. For the past years, people have been using social media for sharing and communicating purpose but after a while, they started to use social media as business platform. Users started to use social media to market their product and engaging with customers. This phenomenon has transformed e-commerce which is a product-oriented environment to a new era of social-commerce where it is more social and customer-oriented (Wigand, Benjamin and Birkland, 2008). McGrath (2016) has carried out a survey to identify the percentage of internet users that have been visited social networks in 2015. Based on four social networks which are Facebook, YouTube, Twitter and Google, Malaysian user has been enlisted in top 10 for at least 3 social networks. This indicates that Malaysia is no exception from following the trend of social media. On top of that, Malaysian internet user has been said to be the most likely to follow brands on social media. Malaysian people have been exposed to the concept of online shopping through social media. Most of the people now prefer to shop online rather than going to physical store. However, with the success of social media as online shopping platform, comes its negative effect. People are potentially threatened by fraud. Talib \& Rusly (2015) in their study described social commerce as a new platform 
INTERNATIONAL JOURNAL OF ACADEMIC RESEARCH IN BUSINESS AND SOCIAL SCIENCES

Vol. 9, No. 1, Jan, 2019, E-ISSN: 2222-6990@ 2019 HRMARS

for their online commercial activities. However social commerce environment and its unique functions allow risk for internet scam to happen. It is believed that as the user's trust towards social media and intention to buy shop through social media increases, it is also will increase the risks and vulnerabilities for scam.

According to onlinefraudguide.com (2017), Malaysia is listed among one of the countries or cities or regions that have a high-risk for online fraud. In 2014, U.S.-based IT security developer SOPHOS ranked Malaysia as sixth globally in terms of cybercrime threat risks, as the total cybercrime bill topped $\$ 300$ million (Mahmood, 2015). The numbers are being said to continue to rise from year to year. The environment of the social media applications enable scammer to trap their victims through a fake profile without being traced. The scammer trapped victims to make payments but never sent them the goods they already paid for. The number of reports received regarding online shopping scam has increased as the popularity of online shopping and online auctions keeps growing. Most of the report complaint about not receiving products they have paid for, products receive late, products received unoriginal and not as per advertised and fail to provide terms and conditions about products and sales (Malaysian Digest, 2015).

According to Selangor Commercial Crimes Investigation Department Deputy Chief Supt Ng Keok Chai (2012), the number of online shopping scam in the state has doubled with increase $50 \% .445$ cases were reported in 2012 compared to 2010 with 247 cases. He also stated that most online scam happen when their money deposited to the seller's account is directed into someone else's bank account.

Meanwhile in 2016, the state recorded total of 302 cases with total losses of RM1.5 million from January to May. The number was expected to continue to rise according to Selangor Commercial Crime Investigation Department Chief Assistant Commissioner, Mohd Sakri Arifin. Based on the reports received, all cases involved customers who do not received their goods even after the payment have been made. He also mentioned that the scammers use social media as the platform to create fake advertisement with attractive offers in order to lure victims (Ruban, 2012).

Study published by Telenor Group (2016) stated that, of the regions surveyed, Malaysia was the country most vulnerable to internet scams, with $46 \%$ of respondents saying they had been victims to scams, followed by Thailand at $43 \%$. It is found that 1 out of 5 people have been scammed by internet auction scams and online dating scam and 1 out of 10 people had their Facebook hacked. In addition to that, $46 \%$ from the respondents agree that they know someone from family and friend who were scam victims. Of those who have been a victim to an online scammer in Malaysia, 6 out of 10 people have lost money, with the average financial loss per person equivalent to RM7050 (\$1,700 US\$). This shows that Malaysia social media security environment is at worrying level. People do not know that they are exposed to the possibilities of being scammed. Some of the seller used fake identity to attract buyers and it is hard to detect them (The Star Online, 2016).

This study is motivated by the need to investigate what possibly be the cause of online shopping scam to occur in social media environment. There have been few major cases of online shopping scam in social media that have been reported in Malaysia and this issue has gotten serious. Numbers of studies on online shopping behavior have been conducted focusing on different area such as demographics, personal characteristic, attitude and intention to shop online. However, this study has found its gap where there are limited studies about online shopping scam especially in Malaysia 
INTERNATIONAL JOURNAL OF ACADEMIC RESEARCH IN BUSINESS AND SOCIAL SCIENCES

Vol. 9, No. 1, Jan, 2019, E-ISSN: 2222-6990 (C) 2019 HRMARS

hence it is a great opportunity to produce research-based evidence as support for the online shopping scam issue. This research will lead to another study in this area and help the government or agencies to propose future guidelines or actions that can be taken in order to prevent this scam in Malaysia.

\section{RESEARCH METHODOLOGY}

\section{A. Data Collection}

1) Survey

Before collecting the real data through survey, pilot study was conducted on 16th November 2016 among 50 Malay students. Pilot study was conducted to test the validity of the question or rephrase the confusing questions based on feedback from the study. Based on the pilot study, few minor changes and addition were made to the questionnaires in order to improve the effectiveness of the questionnaire in evaluating respondent behavior.

2) Target Population

For the purpose of this study, questionnaires were distributed among Malay social media users from all over Malaysia. The questionnaire was distributed through both online and offline survey. The total respondents collected were 201 from all over Malaysia.

3) Sample Size

For data collection, the convenience sampling methods were chosen. Convenience sampling method is where survey was distributed among group of social media users in Facebook, Instagram, and WhatsApp and then they are voluntarily answering the question on their own will. The reason of using this method is because to gain an honest confession and evaluation from each of respondents since this study is about identifying human behavior factors that contribute towards online shopping scam among Malay social media users.

B. Identify the Headings

1) Descriptive Analysis

Descriptive analysis was used to transform and reorganize raw data into an understandable form in order to generate descriptive information. The data collected will be transformed into table and figure form to get a clearer view on the results.

2) Reliability Analysis

The main reason of conducting reliability analysis is to provide a measure of the extent to which an examinee's score reflects random measurement error and to test the validity. The reliability analyses were conducted using Cronbach's Alpha.

3) Log Regression Analysis

Logistic regression predicts a categorical variable from a set of predictor variables. With a categorical dependent variable, discriminant function analysis is usually used if all the predictors are continuous and nicely distributed; log analysis is usually applied if all the predictors are categorical; and logistic regression is often chosen if the predictor variables are a mix of continuous and categorical variables and/or if they are not nicely distributed (Wuensch, 2014). Logistic regression is used because the data is categorical. 
INTERNATIONAL JOURNAL OF ACADEMIC RESEARCH IN BUSINESS AND SOCIAL SCIENCES

Vol. 9, No. 1, Jan, 2019, E-ISSN: 2222-6990 (C) 2019 HRMARS

\section{RESULT \& DISCUSSION}

The relationship between Personal Characteristic and Online Shopping Scam in Social Media

To identify the relationship between personal Characteristic and Online Shopping Scam in Social Media, the result was shown in Table 1.

Table 1: Result of Log Regression Analysis for relationship between Personal Characteristic and Online Shopping Scam in Social Media

\begin{tabular}{|l|l|l|l|l|l|l|}
\hline & B & S.E. & Wald & df & Sig. & Exp(B) \\
\hline AV_PC & -.820 & .450 & 3.320 & 1 & .068 & .441 \\
\hline
\end{tabular}

The above result shows that the relationship between personal characteristics and online shopping scam among social media users was insignificant.

The relationship between Trust and Online Shopping Scam in Social Media

To identify the relationship between Trust and Online Shopping Scam in Social Media, the result was shown in Table 2.

Table 2: Result of Log Regression Analysis for relationship between Trust and Online Shopping Scam in Social Media

\begin{tabular}{|l|l|l|l|l|l|l|}
\hline & B & S.E. & Wald & df & Sig. & Exp(B) \\
\hline AV_TRUST & .285 & .435 & .430 & 1 & .512 & 1.330 \\
\hline
\end{tabular}

Based on hypothesis testing, the result shows that the relationship between trust and online shopping scam among social media users was insignificant.

The relationship between Attraction and Online Shopping Scam in Social Media To identify the relationship between Attraction and Online Shopping Scam in Social Media, the result was shown in Table 3.

Table 3: Result of Log Regression Analysis for relationship between Attraction and Online Shopping Scam in Social Media

\begin{tabular}{|l|l|l|l|l|l|l|}
\hline & & & & & & \\
& B & S.E. & Wald & df & Sig. & Exp(B) \\
\hline AV_ATR & .103 & .395 & .068 & 1 & 0.794 & 1.109 \\
\hline
\end{tabular}

The above result shows that there is no significant relationship between attraction and online shopping scam among social media users.

The relationship between Social Media Environment and Online Shopping Scam in Social Media To identify the relationship between Social Media Environment and Online Shopping Scam in Social Media, the result was shown in Table 4. 
INTERNATIONAL JOURNAL OF ACADEMIC RESEARCH IN BUSINESS AND SOCIAL SCIENCES

Vol. 9, No. 1, Jan, 2019, E-ISSN: 2222-6990 (C) 2019 HRMARS

Table 4: Result of Log Regression Analysis for relationship between Environment and Online Shopping Scam in Social Media

\begin{tabular}{|l|l|l|l|l|l|l|}
\hline & & & & & & \\
& B & S.E. & Wald & df & Sig. & Exp(B) \\
\hline AV_ENV & -.095 & .399 & .056 & 1 & 0.813 & 0.910 \\
\hline
\end{tabular}

The above result shows that the relationship between social media environment and online shopping scam among social media users was insignificant.

The relationship between Intention and Online Shopping Scam in Social Media

To identify the relationship between personal Characteristic and Online Shopping Scam in Social Media, the result was shown in Table 5.

Table 5: Result of Log Regression Analysis for relationship between Intention and Online Shopping Scam in Social Media

\begin{tabular}{|l|l|l|l|l|l|l|}
\hline & & & & & & \\
& B & S.E. & Wald & df & Sig. & Exp(B) \\
\hline AV_INT & .134 & .264 & .257 & 1 & 0.612 & 1.143 \\
\hline
\end{tabular}

The result shows that the relationship between online shopping intention and online shopping scam among social media users was insignificant.

The relationship between Attitude and Online Shopping Scam in Social Media

To identify the relationship between personal Characteristic and Online Shopping Scam in Social Media, the result was shown in Table 6.

Table 6: Result of Log Regression Analysis for relationship between Attraction and Online Shopping Scam in Social Media

\begin{tabular}{|l|l|l|l|l|l|l|}
\hline & & & & & & \\
& B & S.E. & Wald & df & Sig. & Exp(B) \\
\hline AV_ATT & -.258 & .372 & .482 & 1 & 0.488 & .773 \\
\hline
\end{tabular}

The result shows that there is no significant relationship between attitude and online shopping scam among social media users.

Log Regression Analysis on Significant Variables

Another analysis was conducted on indicated variables to come out with the probabilities model. Relationship between certain parameter (State of origin for Sabah category and shopping frequency for twice per week category) in demographic and personal characteristic were used as they are significant in contributing towards online shopping scam. 
INTERNATIONAL JOURNAL OF ACADEMIC RESEARCH IN BUSINESS AND SOCIAL SCIENCES Vol. 9, No. 1, Jan, 2019, E-ISSN: $2222-6990$ (c) 2019 HRMARS

Table 7: Log Regression Analysis on Significant Variables

B

$\begin{array}{lllll}\text { Step 1a } & \text { SR_SOUTH } & 1.617 & .199 & 5.038 \\ & \text { SR_CENTRAL } & 1.723 & .168 & 5.602 \\ \text { SR_NORTH } & 1.900 & .129 & 6.689 \\ \text { SR_EC } & 1.866 & .136 & 6.465 \\ \text { SR_SABAH } & 2.629 & .073 & 13.861 \\ & \text { SF_TPW } & 1.283 & .098 & 3.607 \\ \text { SF_OPW } & .481 & .614 & 1.618 \\ \text { SF_TPM } & .672 & .213 & 1.959 \\ \text { SF_OPM } & .206 & .593 & 1.229 \\ \text { Income_0 } & -.579 & .494 & .561 \\ \text { Income_1 } & 1.005 & .329 & 2.733 \\ \text { Income_2 } & -.604 & .482 & .547 \\ \text { Income_3 } & -.866 & .314 & .421 \\ \text { Income_4 } & -.160 & .866 & .853 \\ \text { AV_PC } & -.717 & .044 & .488 \\ \text { Constant } & .935 & .622 & 2.547\end{array}$

The probability model was constructed using the significant variables. The probability for a respondent being scammed can be calculated from probability model as per below. The value of $Y$ from the probability model should be from 0 until 1 . According to Peng et. al (2002), the value of the coefficient $\beta$ determines the direction of the relationship between $X$ and the logit of $Y$. When $\beta$ is greater than zero, larger (or smaller) $X$ values are associated with larger (or smaller) logits of $Y$. Conversely, if $\beta$ is less than zero, larger (or smaller) $X$ values are associated with smaller (or larger) logits of $Y$. Within the framework of inferential statistics, the null hypothesis states that $\beta$ equals zero, or there is no linear relationship in the population. Rejecting such a null hypothesis implies that a linear relationship exists between $\mathrm{X}$ and the logit of $\mathrm{Y}$.

$$
Y=\beta^{\circ}+(\text { Location })(\beta)+(\text { Shopping Frequency })(\beta)+(\text { Personal Characteristic })(\beta)
$$

The $Y$ value that equal or close to 0 , the respondents is considered to have low chances to be scammed. If the $Y$ value is equal or close to 1 , the respondents are considered to have high chance to be scammed or have been scammed.

Example:

$Y=\beta^{\circ}+($ Location $)(\beta)+($ Shopping Frequency) $(\beta)+$ (Personal Characteristic) $(\beta)$

$Y=(0.935)+(1)(2.629)+(0)(1.283)+(4)(-0.717)$

$\mathrm{Y}=0.696$ 
The sample shown on Table 7 are calculated from information of one of the respondents. The respondent was residing in Sabah and have less than one-month online shopping frequency. The respondent personal characteristics average value was shown mostly at 4 value, which is at agree level. Result shows that the $Y$ value is 0.696 which is closer to 1 . Hence the respondent has high chances of getting scammed. It is proven from the data collected, that the respondent was indeed one of the victims based on the identification question in the last part of the questionnaire.

\section{CONCLUSION}

This research provides a model in conducting study about the influence of online shopping behavior towards online shopping scam in social media that could help to expand the direction of the future study in this area especially in Malaysia. The first objective of this research is to identify consumer online shopping behaviors that contribute towards online shopping scam in social media. Data were collected from social media users in Malaysia that have experience in online shopping through social media. Data were analyzed using Statistical Package for Science Social (SPSS) software and results shows that factor that have significant role in indicating the probability of getting scammed. Consumer personal characteristic could be varied based on their skill, experience and knowledge in online shopping through social media. The second objective of this research is to propose a probability model for anticipation on online shopping scam in social media. Related to the problem statement, few authors from previous study such as Talib \& Rusly (2015) has reported that consumer have certain character such as do not know if they have been scammed or not, do not know what to do when it happened, feel embarrassed with the scam incident and potentially blaming themselves as the cause of what happened. This will lead to number of unreported and unresolved cases. This study proposes a model that can calculate the probability of a consumer being scammed without taking too much information from the victims. This model is also useful to predict their chances of getting scam before it even happened. Therefore, if the results show high probability of the consumer being scammed, early precautions can be made.

\section{RECOMMENDATIONS}

Future researches are suggested to conduct a larger group of respondents that can represent at least half of Malaysia to get more precise analysis results. Moreover, future research can be conducted through interview to get a better perspective from the victims itself. Interview method can encourage victims to open more about their scam experience. Next, research can be conducted from only victim's perspective despite of both category of victims and non-victims. This is to understand the behavior of the victims itself for clearer vision. Based on the analyzed results it showed that only personal characteristic has significant relationship with contributing towards online shopping scam in social media. For future research, more variables can be tested in to find the factors that coming from the victims itself that increase the chances of getting scam.

\section{Acknowledgement}

Highly gratitude goes to the Universiti Teknologi MARA Selangor for funding this work by the internal grant called LESTARI (File no 600-IRMI/MyRA 5/3/LESTARI (0107/2016)). Next, highly appreciation 
INTERNATIONAL JOURNAL OF ACADEMIC RESEARCH IN BUSINESS AND SOCIAL SCIENCES

Vol. 9, No. 1, Jan, 2019, E-ISSN: 2222-6990 (C) 2019 HRMARS

goes to the Faculty of Computer and Mathematical Sciences and Institute of Malay Thought and Leadership of Universiti Teknologi MARA for supporting this study.

\section{Corresponding Author}

Mudiana Mokhsin, Faculty of Computer \& Mathematical Sciences, Universiti Teknologi MARA, 40450 Shah Alam, Selangor, Malaysia.

Email: mudiana.azhar@tmsk.uitm.edu.my

\section{References}

Ruban, A. (2012). Online Shopping scams in Selangor on the rise. The Star Online. Retrieved from http://www.thestar.com.my/news/nation/2012/03/29/online-shopping-scams-in-selangor-onthe-rise/. March 29th 2012.

Cyber Security Malaysia (2014). E-Businesses, Online Shoppers, Job-Seekers urged to be suspicious. MOSTI Media Release. September 10 ${ }^{\text {th }}, 2014$.

Mahmood, M. (2015). Online shopping fraud on the rise. News Straits Times. Retrieved from http://www.nst.com.my/news/2015/09/online-shopping-fraud-rise. August 5 ${ }^{\text {th }}, 2015$.

Malaysian Digest (2015). Malaysia is Becoming A Global Hub For Online Scams, Will You Be The Next Victim?. Retrieved from http://malaysiandigest.com/features/583209-malaysia-is-becoming-aglobal-hub-for-online-scams-will-you-be-the-next-victim.html. December $8^{\text {th }}, 2015$.

McGrath, F. (2016). Malaysian most likely to follow brands on social media. Retrieved from www.globalwebindex.net/blog/malaysians-most-likely-to-follow-brands-on-social-media. June $20^{\text {th }}, 2016$.

Attitude Group Ltd. (2017). Online Fraud Guide by Attitude: A guide to help online merchants prevent the stress and costs of fraud. Retrieved from http://onlinefraudguide.com/. May $25^{\text {th }}$, 2017.

Statistica (2015). Number of social media users worldwide from 2010 to 2020. Retrieved from http://www.statista.com/statistics/278414/number-of-worldwide-social-network-users/. November $11^{\text {th }}, 2016$.

Talib, Y, Y. \& Rusly. F, H. (2015). Falling Prey for Social Media Shopping Frauds: The Victims' Perspective. Proceeding of the International Conference of E-Commerce (ICoEC), Kuching, Sarawak, 2015.

Telenor Group (2016). Asia's Top Internet Scams and How to Stay Safe: Telenor Group Study underscores the importance of protecting personal information online. Retrieved from https://www.telenor.com/asias-top-internet-scams-and-how-to-stay-safe/. January 25 ${ }^{\text {th }}, 2016$.

The Star Online (2016). Malaysia is the most vulnerable country to internet scams in this region. Retrieved from http://www.thestar.com.my/business/business-news/2016/03/11/malaysia-isthe-most-vulnerable-country-to-internet-scams-in-this-region/. March 11 ${ }^{\text {th }}, 2016$.

Wigand, R, T., Benjamin, R, I., \& Birkland, J, L, H. (2008). Web 2.0 and Beyond: Implications for Electronic Commerce. Proceeding of the 10th International Conference on Electronic Commerce (ICEC), pp. 1-5. 